\title{
WHERE WERE THE VOTERS? A SPATIAL ANALYSIS OF THE 2019 SLOVAK PRESIDENTIAL ELECTION ${ }^{1}$
}

\author{
L'ubomír Zvada², Martin Petlach³, Michal Ondruška ${ }^{4}$
}

\begin{abstract}
This paper endeavours to deliver a comprehensive spatial depiction of Slovakia's presidential election held on $16^{\text {th }}$ and $30^{\text {th }}$ March 2019. At first, the text briefly considers electoral and institutional framework of presidential elections and its background. Within the context of the first round, the paper subsequently analyses the electoral support of four key candidates who had obtained at least 10 per cent in order to clarify the overall electoral support. At the municipal level, the analysis of aggregated data then brings a complex mapping of regional electoral support towards the presidential candidates. Our negative binomial regression models, based on socio-economic variables and the results of the 2016 parliamentary election, yield no satisfactory results. Nonetheless, among others, it was revealed that the final two contenders did not lose their voters from the previous round. In comparison to Šefčovič, Čaputová succeeded in acquiring lower levels of new electoral support (up to 20 per cent) but across the whole country. Afterwards, the Hungarian minority was proved a determinative factor for the win, contrarily to the socio-economic indicators as explicative variables of which the university degree and age were found the most significant.
\end{abstract}

KEY WORDS: Slovakia, Slovak politics, Spatial analysis, Presidential election, Electoral support, Regional support, Electoral geography, Political geography.

\section{INTRODUCTION}

Slovakia's 2019 presidential election was the sixth one in the modern history of Slovak Republic as established in 1993. The presidential election,

\footnotetext{
${ }^{1}$ The first author would like to thank Palacký University for financial support. This paper was supported by the project FF_IGA_2019_026.

The authors would like to take this opportunity and thank the reviewers for their valuable remarks, since it has helped to improve the draft considerably. A draft version and its selected electoral maps, as employed in this text, had been delivered as part of a contribution at the conference of "Kam kráčaš demokracia: 1989-2019", held at Pavel Jozef Šafárik University in Košice, Slovakia, on 21-22 November 2019.

${ }^{2}$ Faculty of Arts, Palacký University, Křížkovského 12, 77180 Olomouc, Czech Republic, e-mail: lubomir.zvada01@upol.cz, ORCID: 0000-0003-0869-5014.

${ }^{3}$ Faculty of Regional Development and International Studies, Mendel University, třída Generála Píky 2005/7, 613 00, Brno, Czech Republic, e-mail: martin.petlach@mendelu.cz, ORCID: 0000-0001-5843-5849.

${ }^{4}$ Faculty of Social Sciences, Charles University, U Kříže 8, 158 00, Prague, Czech Republic, e-mail: michal.ondruska@fsv.cuni.cz, ORCID: 0000-0002-1792-6390.
} 
held on $16^{\text {th }}$ and $30^{\text {th }}$ March 2019, has brought breakthrough outcomes. Zuzana Čaputová, a relatively unknown lawyer and activist, has won the presidential election and became the fifth president, and the very first female president of Slovakia.

This result was widely reflected by the world media (Walker, 2019; Mortkowicz, 2019) because Čaputová, supported by a new nonparliamentary political party, Progresívne Slovensko (Progressive Slovakia, PS), defeated her main opponent, the Vice-president of the European Commission for Energy Union, Maroš Šefčovič, a candidate backed up by the long-standing ruling party in Slovakia, Smer-SD (Direction-SD). Furthermore, she has outflanked the rival in both rounds of voting. The newly elected president took office after an inauguration ceremony on $15^{\text {th }}$ June 2019 from the outgoing president, Andrej Kiska, the first independent candidate and a genuine "political novice" in the 2014 presidential election (Rybář, Spáč, 2015).

In the aftermath of Čaputovás victory, and due to the accelerating democratic defects in Central and Eastern Europe reflected by many studies (Ágh, 2016a; Ágh, 2016b; Knott, 2018; Hanley, Vachudova, 2018; Cianetti, Dawson, Hanley, 2018), new hopes were pinned on this fresh political actor. First, for instance, Anne Applebaum had entitled her Washington Times article "Slovakia's president suggests a way out of the world's populist quagmire". And subsequently, in her latest book, she has perceived Čaputová as a presage of "some kind of a new and better (...) political leadership able to unify the citizens regardless of their interests" (Applebaum, 2019; Applebaum, 2020, p. 173).

Despite the fact that this election had been widely recognised as a crucial one in respect of the country's next heading, only study was focused on the role and use of social media in the election (see Švidroňová, Kaščáková, Bambuseková, 2019). For that reason, this paper has been inhered in two primary objectives. At first, this study aims to map and elaborate on the spatial and electoral support at the municipal levels in the 2019 presidential election. Secondly, the paper wishes to assist in making electoral analyses more frequent and common in the area as in case of other European countries wherein scholars put the accent on it greatly (e.g., Fleming, 2006; Maškarinec, 2013). Hence, the paper addresses the following research questions:

- Q1: In which Slovakia's municipalities did the given candidates obtain their core versus minor electoral support?

- Q2: Which socio-economic characteristics and party preferences resulting from the 2016 parliamentary election may be attributed to 
the electorate of examined presidential candidates in the first round?

- Q3: How did the spatial distribution of electoral support vary after the first round? Where did candidates acquire and/or lose the votes?

In order to fulfil the aforementioned goals, the paper is structured as follows. In the first section, the theoretical base is introduced; therefore, an emphasis is put on electoral geography and spatial support. In the meantime, the authors emphasise Slovakia's experience with this type of research and consequently, a certain lack and insufficiency in numbers is presented. Then research questions is addressed concerning the data basic for the analysis. After a brief discussion on the institutional framework and 2019 political background for this presidential election, the spatial and socio-economic analyses may finally be conducted.

\section{ELECTORAL GEOGRAPHY AND THE CONTEXT OF SLOVAKIA}

The outset of electoral geography as a research field may be tracked back to the early $20^{\text {th }}$ century after André Siegfried compared various electoral outcomes in France in Tableau Politique de la France de l'Ouest sous la Troisième République (1913) his magnum opus. As a scientific discipline, political geography was founded by the turn of the 1950s and 1960s, and its popularity peaked in the Anglo-Saxon area in the second half of the 1980s (Leib, Quinton, 2011, p. 9). Pattie and Johnston, however, most aptly defined this scientific discipline as a "subfield of political geography focusing on the interaction of space, place, and electoral processes (...) while the field examines the impact of geographical context on voters' decisions, parties' strategies, and on the operation of electoral systems and forms an interface between human geography and political science" (Johnston, 2000, p. 204; Pattie, Johnston, 2009). Moreover, David Storey delineated three leading areas of interest in case of this subfield: (1) geography of elections (such as the forms of transfer of power); (2) geography of representation (meaning the types of electoral system); and finally (3) voting (implying sundry spatial patterns of voting behaviour) (Storey, 2009, p. 250).

After the breakdown of bipolar structure in the world and the re-creation of new democracies in the area of CEE, electoral geography was founded in Czechoslovakia, too. In Slovakia, nevertheless, electoral geography has lingered as an underestimated section of studies in political science and sociology. As Daniel Kerekeš notes, this discipline simply "does not enjoy great popularity" (Kerekeš, 2018, p. 32). Pioneering contributions may be 
found in the 1990s and were based on comparisons of electoral outcomes and focusing on electoral support towards political entities in the 1990, 1992, and 1994 elections (Baráth at al., 1995). Later, Szőlős (2006) followed these footsteps when analysing the 1998, 2002, and 2006 elections. The work of Vladimír Krivý $(1996 ; 2000 ; 2014)$ stressed more detailed analyses of electoral behaviour, specific for particular areas and respective sociocultural links to regional differences. This sociologist's merit lies in the fact that his texts considered a long-term horizon from the 1990s. By contrast, multifarious studies dealing with particular national and supranational political phenomena, as gradually appearing in Slovakia, may be discerned. Predominantly, a vast majority of these studies have concentrated on the impact of local and regional levels of governance, though. In his analysis of the 2016 election, Hlaváč (2016) even "summarises the election results for the country as a whole, as well as separately by region". In addition, a creeping increase of far-right extremism, represented by Marián Kotleba's party (LSNS) accelerated the scholars' interest in the topic, too in connexion to the spatial support or voting behaviour (e.g., Gregor, 2015; Mikuš, Gurňák, Máriássyová, 2016; Buček, Plešivčák, 2017). Albeit in limited numbers but more valuable per se, there are research studies inquiring electoral geography of smaller territories as in case of Kerekeš (2016). His paper was then dedicated to the "parties' territory of voting support, territory of stable voting support, and spatial variance" in the town of Košice (ibid., p. 31). From a historical angle of analysis, some scholars attempted to describe electoral support and the electorate itself in the interwar period and the era of the First Czechoslovak Republic (e.g., Przybyla, 2019; Madleňák, Balážovič, 2018; Bahna, Krivý, 2016).

In the context of Slovakia, geographers instead of social scientists have shaped the contemporary discourse. Influential papers in this area are attributed to Plešivčák whose analyses has not only borne in mind the role of regions as sources of regional support (e.g., Plešivčák, 2011a), but he put an emphasis on mutual relations amongst socio-economic variables and electoral preferences, whilst not neglecting fundamental theoretical concepts as, for instance, the theory of Rokkan and Lipset on cleavages in Slovakia (see Plešivčák, 2011a; 2011b; 2013; 2014). Furthermore, Madleňák (2012a; Madleňák, Pink, 2012b) characterised fundamental aspects of spatial distributions in terms of electoral strongholds that the then political parties had enjoyed in the period of 1994-2010. Afterwards, Madleňák $(2019 ; 2017)$ specialised either in geographic facets linked to the electoral system in the single electoral district as utilised in Slovakia, or eventually in 
the representation share of individual regions in the NCSR (National Council of the Slovak Republic). The relation between socio-economic variables, pertaining to the electorate in given regions, and electoral outcome were not considered though as in case of the above-mentioned papers of Plešivčák.

As it was delineated, presidential elections and its spatial testing in respect of competitors standing for elections has remained omitted the most. Although some so-called electoral reports might be identified (e.g., Rybár, Spáč, 2015; Rybář, 2010; Rybář, 2005; Fitzmaurice, 2001), their contents and objectives are not being able to elucidate deeper patterns of electoral support at the regional or local level. A study of Pink and Spáč (2012) has represented the one and only endeavour to examine Slovakia's presidential election conscientiously. In this text, the authors divided the presidential candidates from 1999, 2004, and 2009 into five categories, ${ }^{5}$ and their core attention was paid to those candidates who had obtained at least 5 per cent. Interestingly, according to the analysis, the candidates endorsed by political parties usually usurp a higher level of support in the strongholds of given parties, which had propounded the candidates. Non-party candidates, by contrast, tend to succeed in areas known for supporting political parties in close ideological proximity. Hence, a significant effect was proved in terms of partisanships and recommending endorsements as given by political parties. Last but certainly not least, the authors concluded that presidential elections still spun the societal division out (ibid., pp. 199-200). ${ }^{6}$

In this regard, however, there has been a certain lack of in-depth analyses investigating Slovak presidential elections in respect of spatial analyses considering the electoral support at the regional level. And this paper makes an attempt to fill this gap.

\section{DATA AND METHODS}

All the datasets necessary for the coefficient calculations were acquired from the official websites of the Statistical Office of the Slovak Republic and the Ministry of the Interior of the Slovak Republic. In this paper, the authors deliver a dataset of maps depicting the overall electoral support executed by the QGIS software. Subsequently, a raster layer for the level of municipalities,

\footnotetext{
${ }^{5}$ The above-mentioned categories were as follows: 1) mainstream centre-right political candidates; 2) nationalist centre-left candidates; 3) Christian-conservative candidates; 4) civic centre-right independents; 5 ) the others as unclassified candidates.

${ }^{6}$ Apart from the party discipline, a strong impact is attributed to the "modificatory factor" that embodies the leader's personality and charisma (Spáč, Pink, 2012, p. 199).
} 
as polygons, is included. The necessary data are available online at the Geoportal website. ${ }^{7}$ In respect of the first research question, the authors differ from previous studies, and thus they use municipalities as the prime measuring unit in order to map the electoral support. Hence, the statistical models are based on the $\mathrm{N}=2,926$. For the analysis of successful candidates, the authors condition the gain of at least $10 \%$ of votes. Hence, there are four candidates examined, namely Zuzana Čaputová, Maroš Šefčovič, Marian Kotleba, and Štefan Harabin. For acquiring an improved map lucidity and chances to compare the candidates better, a uniform quartile margin opts for as follows: $0.00-19.99 ; 20.00-39.99 ; 60.00-79.99$, and $80.00<$ per cent.

The authors address the second research question on socio-economic features whilst using these independent variables: University degree; aged $61+$; unemployed; divorced; Roman Catholic; Hungarian affiliation. ${ }^{8}$ In respect of the analysed data exemplifying the electoral turnout in case of Slovakia's presidential election, the data distribution turned out to be diverse (see Graph 1 and Table 1). There was a higher number of municipalities with candidates acquiring a lower number of votes whilst reaching higher figures, and at the same time there was a lower number of municipalities in which the candidates had obtained a higher number of votes.

Graph 1: Distribution of Electoral Results by Selected Candidates Electoral results - Histogram
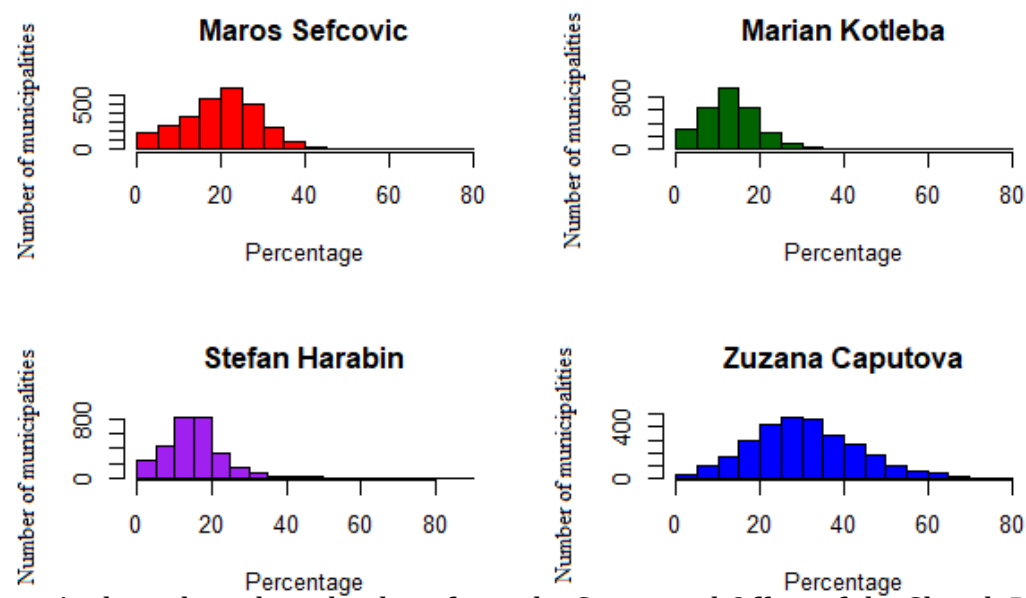

Source: Authors, based on the data from the Statistical Office of the Slovak Republic.

${ }^{7}$ The raster layer is available here: https://www.geoportal.sk/sk/kataster-nehnutelnosti/nastiahnutie/?fbclid=IwAR37T44XQ-Y19euRIsVZbjI4Ze-yXrmgUSxSwRyaDlnuw6Q9yaV9eQ0gOVQ.

${ }^{8}$ The variables follow the patterns of the Population and Housing Census (2011). 
Table 1: Distribution of Electoral Results by Selected Candidates

\begin{tabular}{ccccc}
\hline Candidates & Skewness & Kurtosis & Mean & Variance \\
\hline Zuzana Čaputová & 0.31 & 3.1 & 30.83 & 156.76 \\
Maroš Šefč́ovič & 0.23 & 3.91 & 20.29 & 86.6 \\
Marian Kotleba & 1.25 & 7.52 & 13.55 & 53.11 \\
Štefan Harabin & 1.35 & 8.55 & 15.33 & 65.55 \\
\hline
\end{tabular}

Source: Authors, based on the data from the Statistical Office of the Slovak Republic.

It is palpable that the highest figures are individual in case of each candidate. However, the data distribution has been proved to be inclined to the left, i.e. towards 0 , in all the analysed examples, including the dataset of Zuzana Čaputová, albeit in a moderate mode. Inclinations that are more puissant prevailed amongst the datasets of Kotleba, Harabin, and Šefčovič. After conducting a partial analysis for each candidate, the authors have ascertained that the values of variance were higher than the mean values. Therefore, the authors have decided to use the negative binomial regression as regularly employed in social sciences (UCLA, 2020; Hilbe, 2011; Allison, Waterman, 2002; Land, McCall, Nagin, 1996), instead of ordinary least squares regression (OLS). OLS calculates the line of relation corresponding to the manifested data in accordance with given mathematical criterion. In case of OLS, it enumerates a line minimising the distance differences between the calculated line and the real data. Linear regression is used in cases possessing the normal data distribution, meaning that its histogram appears to follow the Gaussian distribution, thus a bell curved. The aforementioned type of data tends to have various features, and apart from the distribution, it is skewness and kurtosis of which values extend to 0 in both cases. ${ }^{9}$ (Mareš, Rabušic, Soukup, 2015). Furthermore, the authors endeavour to analyse possible connexions amongst candidates and electoral outcomes from the 2016 general election. Therefore, in the model, all the parties that had surpassed the 5 per cent threshold shall be figured in.

With regard to the third question inquiring two main rivals, Zuzana Čaputová and Marián Šefčovič, no additional analysis of geographical results is to be conducted. Instead of this, the authors employ a modified hotspot analysis ${ }^{10}$ in which, thanks to the QGIS programme, all the votes for the two

${ }^{9}$ The Kolmogorov-Smirnov test represents another way in which the normal distribution may be tested.

${ }^{10}$ The hotspot analysis elucidates where the examined elements cluster (see, desktop.arcgis.com). 
candidates are to be calculated as a difference between the groups of votes from the first and the second round. Afterwards, these calculations shall expose the territories with the voters' shifts in the course of the two voting rounds. Once again, the quartile range of similar character is to be used as in case of electoral support for candidates in the first round. This time, though, the margin figures might gain a negative dispersion too.

\section{ELECTION BACKGROUND}

Presidential election held in March 2019 was the fifth to use the direct ballot, whilst applying the two-ballot system, often characterised as the "absolute majority system with a runoff "or "second ballot majority-runoff system" (Norris, 1997, p. 302; Chytilek et al., 2009, p. 28). ${ }^{11}$ The Slovak constitution defines the president as the "Head of State" who "represents the Slovak Republic both outwardly, and through his/her decisions ensures the due performance of constitutional bodies", making the president part of the executive. In addition, the president is a "Supreme Commander of armed forces" and in some particular cases he or she "may dissolve the Národná rada Slovenskej republiky" (hereinafter referred to as the NRSR or National Council of the Slovak Republic). ${ }^{12}$

Slovakia's 2019 presidential election was conspicuously determined by the domestic political background much more than any other election ever. The Government was formed after the 2016 general election which brought an unwonted and ideologically-heterogeneous coalition composed of social democratic Smer-SD, nationalist Slovenská národná strana (SNS, Slovak National Party), centre-right \#Siet' (\#Network), and Most-Híd (The Bridge), a Slovak-Hungarian party (Just, 2019; Rybář, Spáč, 2017; Zvada 2018; Filipec 2019). This Fico's third Cabinet was set up and agreed, although, in their campaigns the latter two political parties openly proclaimed that lacked any intention to join a coalition composed of Fico's Smer-SD. Moreover, one

\footnotetext{
${ }^{11}$ For more information, about the presidential competences see the Constitutional Bills No 9/1999 and No 46/1999. Also some studies concerned and evaluated impact of the direct ballot in Slovakia (e.g. Giba, 2011; Horváth, Juhás, 2011).

${ }^{12}$ The most essential and visible presidential competence is to "appoint and recall the Prime Minister (PM), other members of the Government of the Slovak Republic, the heads of central bodies and higher-level state officials, university rectors, university professors, generals, and chiefs of diplomatic missions" (The Slovak Constitution, 1993, Articles 101-107). The Slovak president also has the right to use a suspensive veto. He or she has, however, no right to propose a new bill to the NRSR, whereas, for instance, the president of Poland is allowed to do so (Fitzmaurice, 1998, p. 70).
} 
of the traditional Slovak parties, Krestansko-demokratické hnutie (KDH, Christian-Democratic Movement) remained out of the NRSR. However, two new populist forces, Sme Rodina (We Are a Family) or the extreme right party Kotleba - L'udová strana naše Slovensko (L'SNS, Kotleba - People's party our Slovakia) entered the Parliament thanks to their ability to promote vehemently anti-immigrant and anti-Muslim rhetoric (Zvada, 2018, p. 217).

A strong ideological discrepancy could be witnessed amongst the highest Slovak representatives, i.e. the leaders of ruling coalition parties, Fico who had been Kiska's main opponent in the 2014 presidential election, and the Speaker of the NRSR, Andrej Danko. Political tensions intensified after Ján Kuciak, an investigative journalist, and his fiancée, Martina Kušnírová, were savagely murdered in their house on $21^{\text {st }}$ February 2018. The violent murder of those young people led the Slovak society into a deep political depression which even escalated into an initiative called Za slušné Slovensko (For a Decent Slovakia). This movement then organised the greatest protest rallies in many Slovak cities. The capital of Bratislava hosted the largest protest events since the fall of communism in 1989.

Moreover, the importance of this presidential election intensified the fact that the ruling and most dominant party of the last decade, Smer-SD, had faced a constant decrease of votes as exemplified in the 2017 regional election when this party lost its seats of regional governors ${ }^{13}$ in four out of six regions. Similarly, in the 2018 municipal election, the party lost 255 seats in municipal assemblies if comparing to the 2014 election. Together with the European Parliament election, this presidential election was meant to test the party of Smer-SD before the 2020 general election.

When bearing in mind the presidential election as a clash of the ruling and opposition efforts, two pivotal points in both poles, the governmental and opposition, may be identified.

The first one is linked to a recruiting strategy as in existence within the strongest political party, Smer-SD. After having difficulty in rebuilding the coalition underlined by the most massive protest rallies in Slovakia's modern era, the opinion polls implied Smer-SD's continuous diminution. Therefore, they used a very cautious tactics and postponed this announcement of its candidate. Regardless of the opinion polls and its speculations whether Fico wished to run for presidency, his genuine plan, however, was to persuade Miroslav Lajčák to candidate. It seemed that most of the time, the Smer$S D$ Chair tried to convince Lajčák even though he had denied steadily. Furthermore, Lajčák was in an open intraparty conflict with Fico and

${ }^{13}$ Informally called a "župan". 
other party and government colleagues because they refused to promote or even sign the UN document of Global Compact for Migration. After this turbulent debate, it was more than obvious that Fico's party would have to choose another person. Finally, Smer-SD nominated Maroš Šefčovič, Slovakia's highest representatives within the EU, right a couple of hours before the deadline was due. Šefčovičs nomination gradually acquired more support amongst the MPs of $S N S$ with no candidate proposed finally although mentioning its chair, the NRSR Speaker, Andrej Danko, as a possible contender quite frequently. The centre-liberal party, strongly oriented towards Hungarian voters, Most-Híd, nominated its own party leader, the NRSR Vice-chairman, Béla Bugár. This nomination was a pragmatic step to coalition partners on one hand, and Bugár's nomination may be even appraised as a counterweight to the candidacy of Jószef Menyhárt, the leader of Strana mad'arskej komunity (SMK, Party of Hungarian Community).

Secondly, and albeit dissimilar in its characteristics, it is indispensable to consider the tenseness of the ways in which the bloc of opposition parties recruited own candidates. In general, political parties, which had gained the mandates in the general election, remained fragmented in the opposition, and so these parties preferred to captivate the voters separately via their own candidates. The opposition party Sloboda a Solidarita, (SaS, Freedom and Solidarity, led by Richard Sulík, a member of the European Parliament) introduced its own candidate, Róbert Mistrík (a scientist and $S a S$ co-founder) inactive in politics for a long time. The NRSR newcomers of the 2016 general election, the populist movement Sme Rodina, led by Boris Kollár, a controversial billionaire, had chosen Milan Krajniak as the party's candidate, and the extreme right party, L'SNS, picked its own leader, Marian Kotleba.

Forthwith, the first opinion polls predicted that the contender to be elected the next president was one of the four-some of Maroš Šefčovič, Štefan Harabin, Robert Mistrík, or Zuzana Čaputová. Two of them clearly represented the back then political milieu, whereas the other two declared new beginnings in Slovak politics as well as a different way of policymaking, based on transparency and decency. Since the polling day was announced, from January and the first half of February, Čaputová had pursued Mistrík's in placings. Since the second half of February, she literally took the lead. For that reason, on $26^{\text {th }}$ February, Mistrík followed the prior agreements and stood down from the presidential campaign in favour of Čaputová. At the ensuing press conference, he expressed his support to her and stated that "no mouthpiece of Robert Fico or Vladimír Mečiar shall ever be allowed to 
take office as the president". Čaputová achieved a backup from the outgoing President Kiska after that (Mikušovič 2019; Tkáč 2019).

Finally, the candidates may be divided into three categories. First category are marginal candidates who were predominantly unknown to the public, or well-known only in very limited circle of voters, thereby having no support of relevant political parties. ${ }^{14}$ Second category are popular public personalities endorsed by the parliamentary or non-parliamentary parties, more or less connected to their political background..$^{15}$ Third category comprise active politicians representing parliamentary or non-parliamentary political forces. ${ }^{16}$

\section{THE RESULTS, SPATIAL SUPPORT, AND VOTERS' CHARACTERISTICS}

The final score of the first round followed and fulfilled the latest predictions of opinion polls (Focus, 2019). Zuzana Čaputová has reached $40.57 \%$ and Maroš Šefčovič gained $18.66 \%$. The turnout rate was $48.74 \%$ in the first round that is 5 per cent more than in the previous 2014 presidential election, and the second highest since 1999. In the first round, she gained more than twice as much votes as Šefčovič.

Table 2: Complete Results of the 2019 Presidential Election

\begin{tabular}{|c|c|c|c|c|}
\hline \multirow{2}{*}{ Candidate } & First round & First round & Second round & Second round \\
\hline & (votes) & (\%) & (votes) & (\%) \\
\hline Z. Čaputová & 870,415 & 40.57 & $1,056,582$ & 58.40 \\
\hline M. Šefčovič & 400,379 & 18.66 & 752,403 & 41.59 \\
\hline Š. Harabin & 307,823 & 14.34 & & \\
\hline M. Kotleba & 222,935 & 10.39 & & \\
\hline F. Mikloško & 122,916 & 5.72 & & \\
\hline B. Bugár & 66,667 & 3.1 & & \\
\hline M. Krajniak & 59,464 & 2.77 & & \\
\hline E. Chmelár & 58,965 & 2.74 & & \\
\hline Others (5) & 31,274 & 1.42 & & \\
\hline
\end{tabular}

${ }^{14}$ Martin Daňo, Róbert Švec, Bohumila Tauchmannová, Juraj Zábojník, Ivan Zuzula.

${ }^{15}$ Zuzana Čaputová, Štefan Harabin, Eduard Chmelár, František Mikloško, Robert Mistrík.

${ }^{16}$ Béla Bugár, Marian Kotleba, Milan Krajniak, József Menyhárt, and Maroš Šefčovič. 


\begin{tabular}{|c|c|c|c|c|}
\hline Electorate & $4,429,033$ & & $4,419,883$ & \\
\hline Turnout & $2,158,859$ & 48.74 & $1,847,417$ & 41.79 \\
\hline Invalid & 12,848 & 0.59 & 38,130 & 2.06 \\
\hline
\end{tabular}

Source: Authors, based on the data from the Statistical Office of the Slovak Republic and the Ministry of the Interior of the Slovak Republic.

Čaputová's victory was substantial and supported by the fact that she dominated in all of the eight Slovak regions in the first round, and seven out of eight regions in the second round, respectively. At the same time, however, it was a presidential victory burdened with the turnout of $41.79 \%$, the lowest turnout in the second round ever. Apart from the lowest turnout in history, this presidential election has encountered remarkably the highest number of invalid votes comprising of $2.06 \%(38,130)$ in the second round. Slightly smaller numbers of invalid votes nominally represented the first direct election in 1999 accounting for 36,022 of invalid votes. It was, however, with a $73.89 \%$ turnout.

Regarding to Čaputová's supportive votes in the first round, as in Graph 2 , it is palpable that the most concentrated support appeared in the capital, Bratislava, and other parts of the Bratislava region. Both the southern part of Trnava and the Nitra region were significant strongholds of Čaputovás support; especially palpable in the sub-areas of regional towns, such as Banská Bystrica and Košice. By analogy, next relevant clusters of support took place in the districts of Liptovský Mikuláš, Poprad, and Rožňava. In other regions, however, her electoral support was evenly distributed. 
Graph 2: Valid Votes (\%) for Zuzana Čaputová in the $1^{\text {st }}$ Round of 2019 Presidential Election

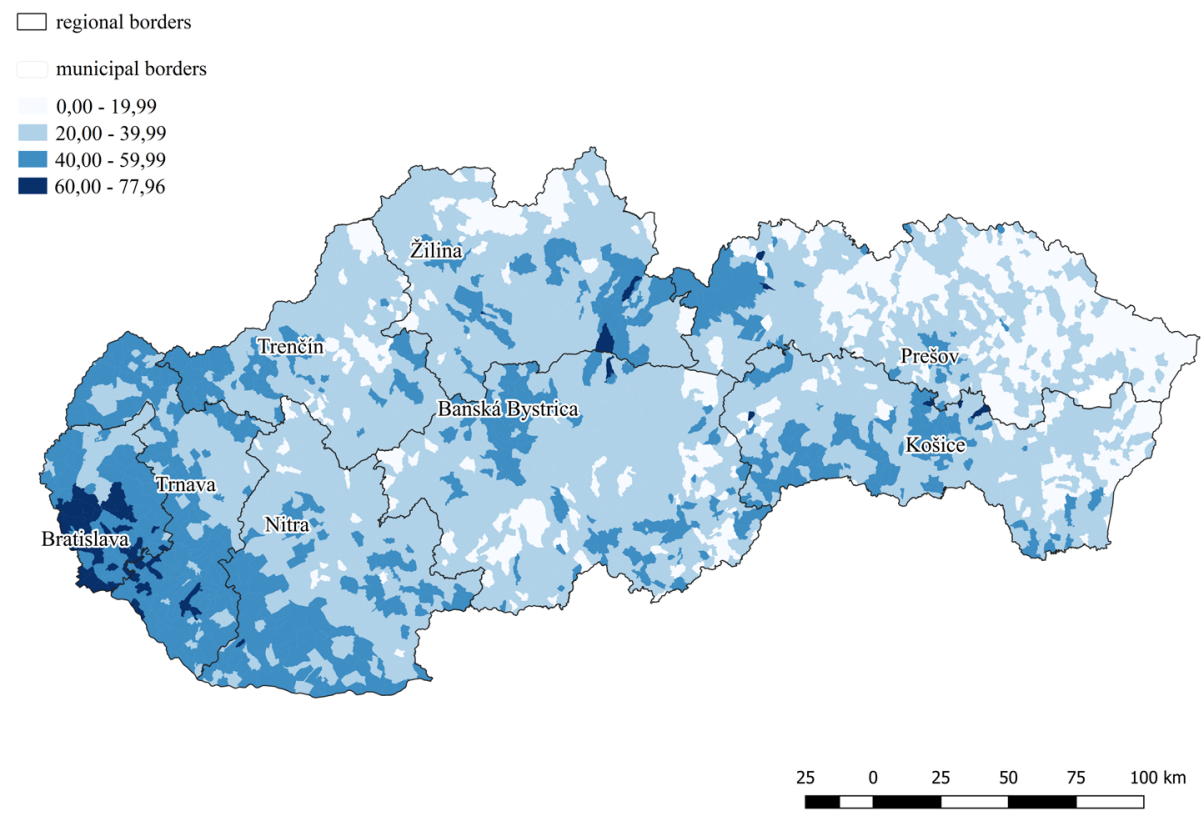

Source: Authors, based on the data from the Statistical Office of the Slovak Republic

By contrast, Čaputová then received a low level of support from voters located in the north (Kysuce) and northeastof Slovakia (Prešov and the eastern part of the Košice region) wherein the Smer-SD party usually dominates the elections. As depicted in the respective map, her electoral support ranging between 0 and 19.99 per cent prevailed in 558 municipalities; 20.00-39.99 per cent support in 1,702 municipalities; $40.00-59.99$ per cent in 612; 60.00-79.99 per cent in 54 municipalities. Čaputová did not gain more than 80.00 percent in any municipality in Slovakia

In comparison with Čaputová, Šefčovič predominantly won only in the eastern part of Slovakia; namely in the eastern areas of the Košice and Prešov regions, while including the districts such as Bardejov, Svidník, Medzilaborce, Humenné, and Stropkov, all of which previously long-dominated by Smer-SD party in all the types of elections. As evident in Graph 3 showing Šefčovič's electoral support, the average figure oscillating between $20-40 \%$ may be found in the Trenčín region (Považie) and the northern part of the Nitra region and northern part of the Žilina region (Kysuce). Interestingly, 
moreover, Šefčovič did succeed on the outskirts of regions, but not in the regional towns as such. On the other hand, a very marginal level of support occurred in the Bratislava region, the southern part of the Trnava region, near the Hungarian borders inhabited by the Hungarian minority, and in the south of Slovakia as a whole. Relatively low figures of support ranging up to 20 per cent were in the regions where the Smer-SD party frequently wins the elections, as for instance in the regions of Spiš and Orava.

Graph 3: Valid Votes (\%) for Maroš Šefčovič in the $1^{\text {st }}$ Round of 2019 Presidential Election

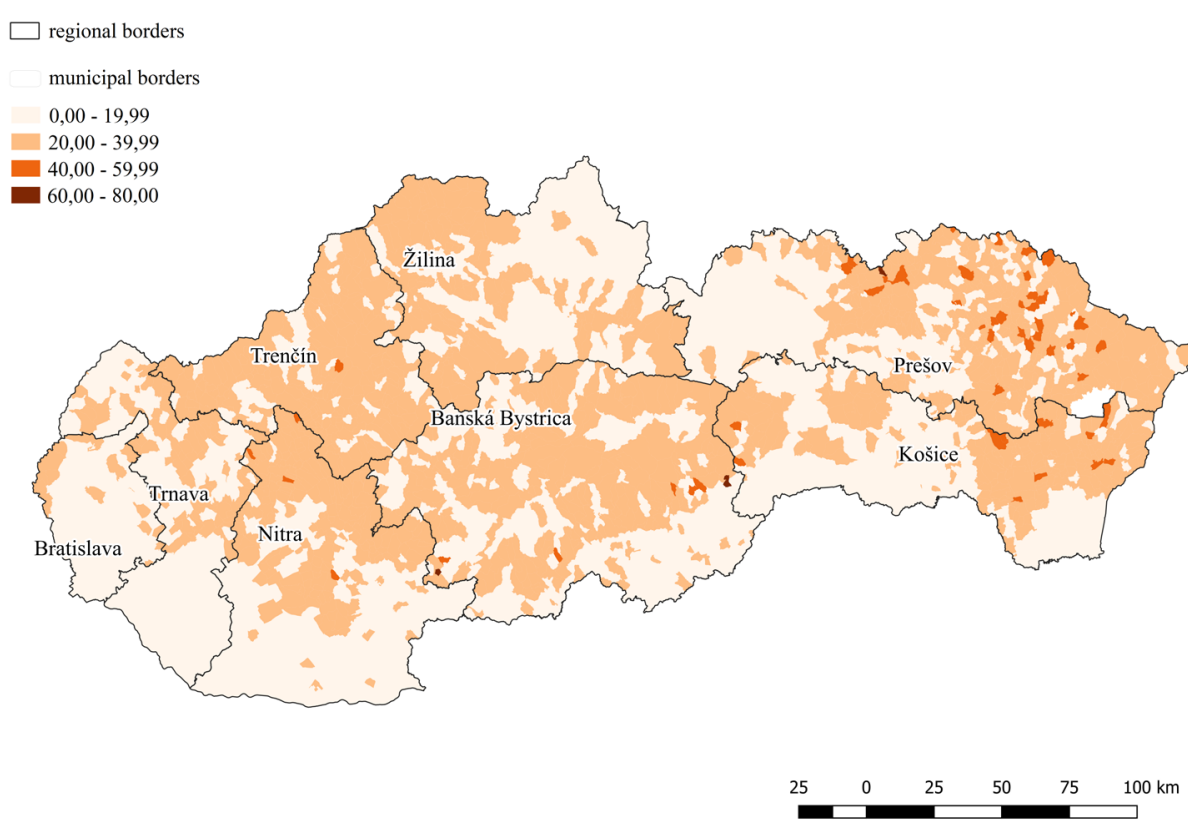

Source: Authors, based on the data from the Statistical Office of the Slovak Republic

Šefčovič's electoral support may be found in Graph 3, and numerically it stands as follows. His electoral support ranging from 0 to 19.99 per cent rose up in 1,362 municipalities; $20.00-39.99$ per cent in 1,506 municipalities; 40.00-59.99\% in just 55 municipalities; $60.00-79.99 \%$ in 2 municipalities; and finally, in 1 municipality his electoral support exceeded 80 per cent.

A truly unforeseen number is represented by the total of Harabin and Kotleba's votes accounting for nearly 25 per cent. The roots of Harabin's voters are akin to Šefčovič’s in the eastern area of the Prešov and Košice 
region, and particularly in the districts such as Svidník, Medzilaborce, and Snina. Not negligible cluster of support was revealed in the region of Poprad and on its outskirts, or in the district of Kežmarok.

Graph 4: Valid Votes (\%) for Štefan Harabin in the $1^{\text {st }}$ Round of 2019 Presidential Election

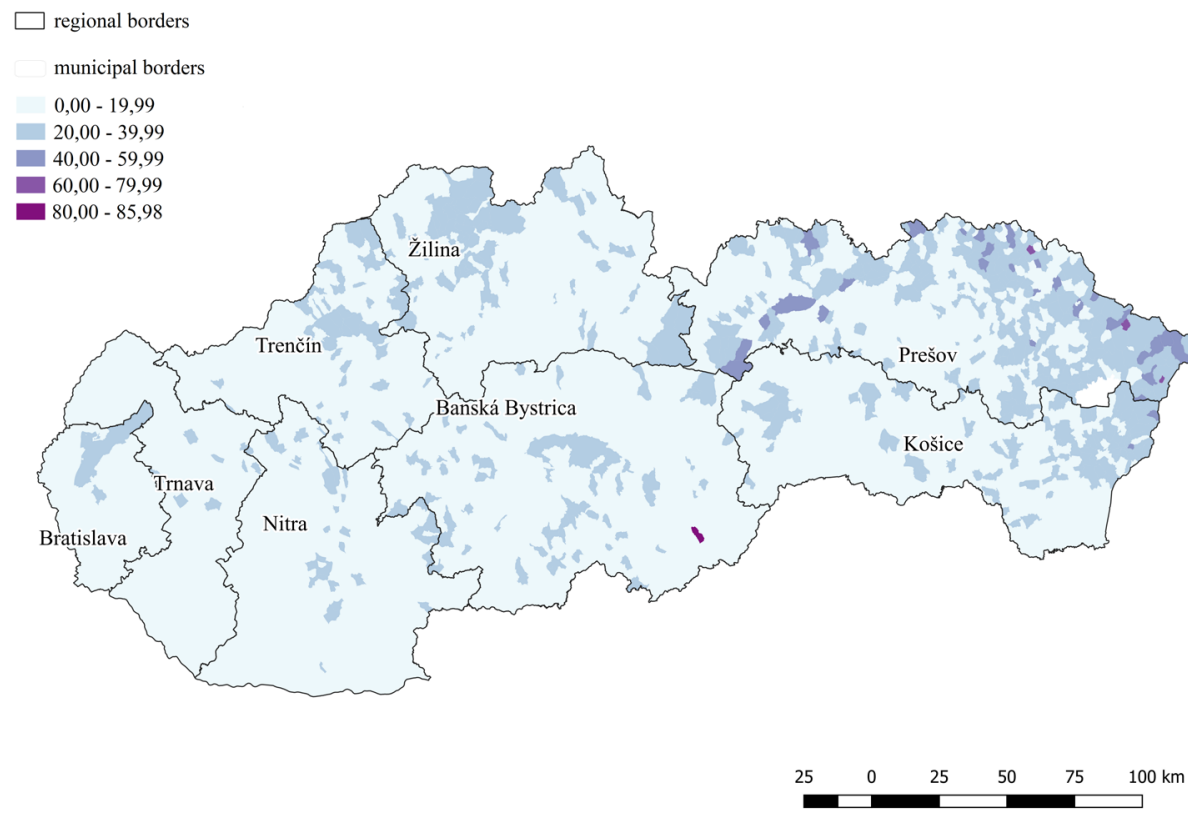

Source: Authors, based on the data from the Statistical Office of the Slovak Republic.

Harabin's core supporters also emerged in the northern area of the Žilina and Trenčín region. The greatest overlap of Harabin and Kotleba's voters was spotted in the region of Banská Bystrica. Apart minor exceptions, Harabin did not obtain any votes from the regions of Bratislava, Trnava, and Nitra. Harabin's ca 308,000 voters from the first round were segmented as follows: 0-19.99 per cent in 2,301 municipalities; 20.00-39.99 per cent in 587 municipalities; 40.00-59.99 per cent in 34 municipalities; 60.00-79.99 in 4 municipalities, and finally 80 per cent and more in no municipality.

Kotleba's most conspicuous landslide victory occurred in the Banská Bystrica region where he took a position of a regional governor from 2013, and in the north of the Žilina region then. 
Graph 5: Valid Votes (\%) for Marian Kotleba in the $1^{\text {st }}$ Round of 2019 Presidential Election

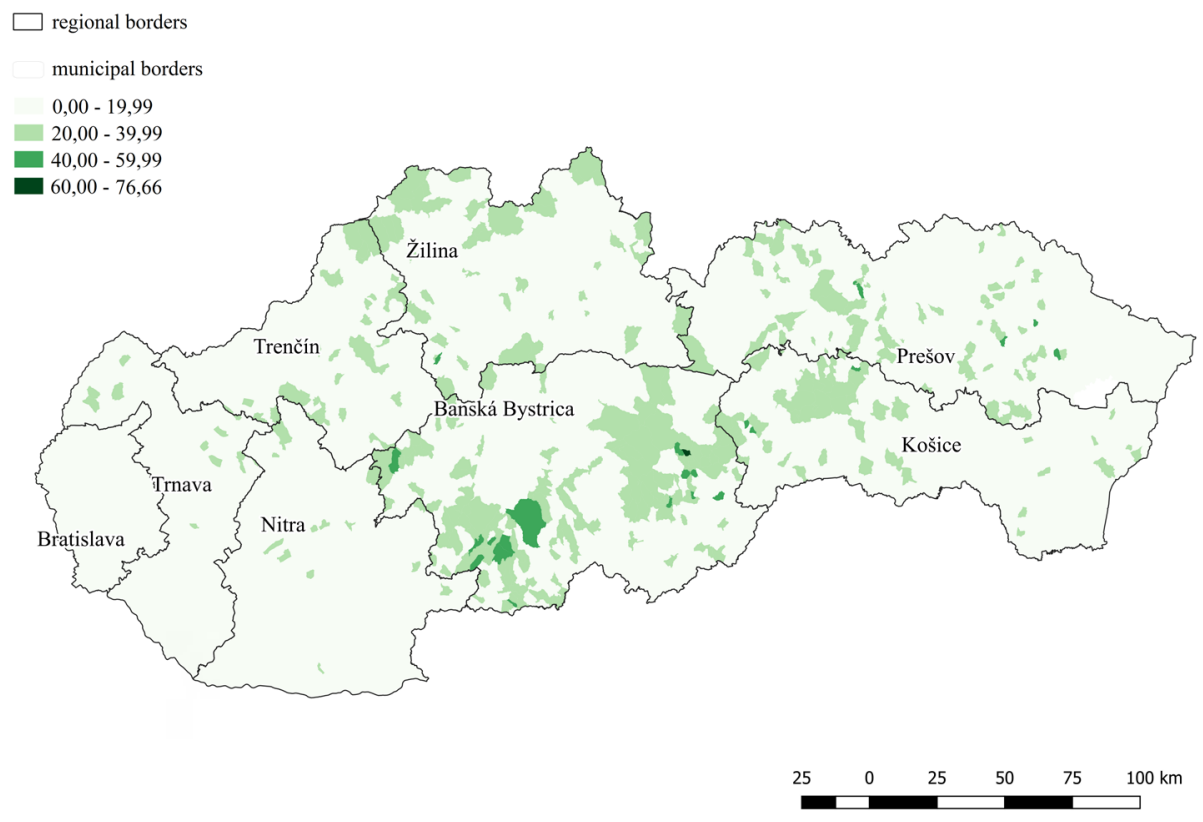

Source: Authors, based on the data from the Statistical Office of the Slovak Republic.

In the region of Banská Bystrica, Kotleba dominated the two upper quartiles ranging from 40.00 to 80.00 per cent, especially in the municipalities of Krupina, Detva, Rimavská Sobota, Rožňava, Revúca, and Žarnovica. Regarding to the area of northern Slovakia, he succeeded in the regions of Trenčín (Horné Považie) and Žilina (Kysuce), particularly in the territory under the towns of Považská Bystrica, Čadca, and Bytča. Overall, the electoral support of the three aforementioned candidates mostly overlapped. Contrarily, Kotleba's failure was even greater than Harabin's in the regions of Bratislava, Trnava, and Nitra. Kotleba's campaign was not successful in the northern area of Slovakia, northern part of Prešov, and southeast part of the region of Košice. Overall, nonetheless, the highest share of electoral support may be found in the margin of 0-19.99 per cent, and it was in 2,487 municipalities; the electoral support between 20.0039.99 per cent appeared in 415 municipalities; $40.00-59.99$ per cent in 22; 60.00-79.00 per cent in just 2 municipalities. He failed to obtain votes over 80 per cent in any municipality. 
Considering the electoral maps, two points are to be foregrounded. First, it is feasible to observe a geographical division in case of Slovakia. This division then results in the political cleavage, mostly urban-rural based one. This urban-rural cleavage has been persistent in the Slovak presidential elections (Pink, Spáč, 2012). And the question is, what are the effects of the 2019 presidential election on the spatial patterns in a long run. Whether, against all odds, a new trajectory based on Čaputová's victory is to be followed or remains unchallenged instead as in case of mainstream centreright candidates (e.g., Kukan, Radičová) or civic centre-right candidates (e.g., Vašáryová, Bútora), who did not succeed in predominantly conservatively nationalistic areas of Slovakia, as previously delineated by Pink and Spáč (2012). Second, there are polygons of higher electoral support towards particular candidates and these correspond to higher electoral results for political parties endorsing the given candidates. This aspect will be further elaborated in the paper. However, due to the highly personalised form of elections, there are many polygons with merely "around average" electoral results. Moreover, contrary to the parliamentary elections, medium-scale or large areas with no support might be spotted when using the certain method in geographic visualisation. These "blank spots", more frequently than ever, do not correlate. This is the reason why in the following model regressing election results of presidential candidate by the party election results does not yield any satisfying results.

The resultant models of binomial regression, however, have not provided sufficiently significant outcomes. Albeit in a correct utilisation, the models have manifested solely frail or no relations amongst independent and dependent variables. There are two explanations to be pondered upon. First, it had been caused by the personalised form of voting in presidential elections per se, as further in this text. Secondly, the data aggregated at the municipal level do not allow exposing the connexions within the analysed units, and thus have biased the results. Nevertheless, when considering even the lower figures of the coefficients acquired in the party model, it is palpable that the candidates, who were official members of political parties or merely endorsed thereof, have obtained higher figures of given coefficients as in the cases of, for example, Maroš Šefčovič's Smer-SD and Kotleba's L'SNS.

As in Table 3, the model did not yield any sufficient results. Some certain trends, however, might be observed. Education represented by the level of university degree is proved the highest amongst the voters of Čaputová. By contrast, this variable has scored lower in case of other candidates. At 
the same time, the age of $61+$, as a variable, is present mostly across the electorate of Šefčovič.

Table 3: Socio-Economic Model for the $1^{\text {st }}$ Round of Election: The Negative Binomial Regression

\begin{tabular}{|c|c|c|c|c|c|c|}
\hline \multirow{2}{*}{$\begin{array}{c}\text { Variable } \\
\text { university degree }\end{array}$} & \multicolumn{2}{|c|}{ Zuzana Čaputová } & \multicolumn{4}{|c|}{ Maroš Šefčovič } \\
\hline & 0.034 & $(0.000)$ & $* * *$ & -0.028 & $(0.000)$ & $* * *$ \\
\hline aged $61+$ & -0.002 & $(0.000)$ & $* * *$ & 0.016 & $(0.000)$ & $* * *$ \\
\hline unemployed & -0.010 & $(0.000)$ & $* * *$ & 0.000 & $(0.000)$ & $*$ \\
\hline divorced & 0.010 & $(0.000)$ & $* * *$ & 0.006 & $(0.000)$ & $* * *$ \\
\hline Roman Catholic & 0.000 & $(0.000)$ & $* * *$ & -0.002 & $(0.000)$ & $* * *$ \\
\hline Hungarian & 0.006 & $(0.000)$ & $* * *$ & -0.017 & $(0.000)$ & $* * *$ \\
\hline Constant & 3.259 & $(0.001)$ & $* * *$ & 3.082 & $(0.001)$ & $* * *$ \\
\hline Pseudo Rsq & 0.097 & & & 0.138 & & \\
\hline No. of observations & 2926 & & & 2926 & & \\
\hline Variable & \multicolumn{2}{|c|}{ Štefan Harabin } & \multicolumn{4}{|c|}{ Marian Kotleba } \\
\hline university degree & -0.022 & $(0.000)$ & $* * *$ & -0.066 & $(0.000)$ & $* * *$ \\
\hline aged $61+$ & -0.006 & $(0.000)$ & $* * *$ & -0.004 & $(0.000)$ & $* * *$ \\
\hline unemployed & -0.002 & $(0.000)$ & $* * *$ & 0.005 & $(0.000)$ & $* * *$ \\
\hline divorced & 0.001 & $(0.000)$ & $* * *$ & 0.017 & $(0.000)$ & $* * *$ \\
\hline Roman Catholic & -0.002 & $(0.000)$ & $* * *$ & 0.003 & $(0.000)$ & $* * *$ \\
\hline Hungarian & -0.015 & $(0.000)$ & $* * *$ & -0.015 & $(0.000)$ & $* * *$ \\
\hline Constant & 3.211 & $(0.001)$ & $* * *$ & 2.837 & $(0.001)$ & $* * *$ \\
\hline Pseudo Rsq & 0.110 & & & 0.157 & & \\
\hline No. of observations & 2926 & & & 2926 & & \\
\hline
\end{tabular}

Source: Authors, based on own calculations.

All models are weighted by the population. $\left({ }^{*}=p \leq 0.05 ;^{* *}=p \leq 0.01 ;{ }^{* * *}=p \leq 0.005\right)$. 
Table 4: Party Model for the $1^{\text {st }}$ Round of Election: The Negative Binomial Regression

\begin{tabular}{|c|c|c|c|c|c|c|}
\hline \multirow{2}{*}{$\begin{array}{c}\text { Variable } \\
\text { SaS }\end{array}$} & \multicolumn{2}{|c|}{ Zuzana Čaputová } & \multicolumn{4}{|c|}{ Maroš Šefčovič } \\
\hline & 0.023 & $(0.000)$ & $* * *$ & 0.005 & $(0.000)$ & $* * *$ \\
\hline \#Siet ${ }^{\prime 17}$ & 0.000 & $(0.000)$ & $* * *$ & 0.006 & $(0.000)$ & $* * *$ \\
\hline L'SNS & -0.011 & $(0.000)$ & $* * *$ & 0.003 & $(0.000)$ & $* * *$ \\
\hline Smer-SD & -0.009 & $(0.000)$ & $* * *$ & 0.025 & $(0.000)$ & $* * *$ \\
\hline SNS & -0.010 & $(0.000)$ & $* * *$ & 0.018 & $(0.000)$ & $* * *$ \\
\hline Most-Híd & 0.005 & $(0.000)$ & $* * *$ & -0.003 & $(0.000)$ & $* * *$ \\
\hline Sme rodina & 0.022 & $(0.000)$ & $* * *$ & 0.013 & $(0.000)$ & $* * *$ \\
\hline OL'aNO & 0.005 & $(0.000)$ & $* * *$ & 0.007 & $(0.000)$ & $* * *$ \\
\hline Constant & 3.574 & $(0.001)$ & $* * *$ & 1.739 & $(0.002)$ & $* * *$ \\
\hline Pseudo Rsq & 0.191 & & & 0.203 & & \\
\hline No. of observations & 2926 & & & 2926 & & \\
\hline Variable & \multicolumn{2}{|c|}{ Štefan Harabin } & \multicolumn{4}{|c|}{ Marian Kotleba } \\
\hline SaS & -0.005 & $(0.000)$ & $* * *$ & -0.036 & $(0.000)$ & $* * *$ \\
\hline \#Siet' & 0.015 & $(0.000)$ & $* * *$ & 0.008 & $(0.000)$ & $* * *$ \\
\hline L'SNS & 0.017 & $(0.000)$ & $* * *$ & 0.063 & $(0.000)$ & $* * *$ \\
\hline Smer-SD & 0.017 & $(0.000)$ & $* * *$ & 0.008 & $(0.000)$ & $* * *$ \\
\hline SNS & 0.019 & $(0.000)$ & $* * *$ & 0.017 & $(0.000)$ & $* * *$ \\
\hline Most-Híd & 0.002 & $(0.000)$ & $* * *$ & 0.001 & $(0.000)$ & \\
\hline Sme rodina & 0.011 & $(0.000)$ & $* * *$ & 0.015 & $(0.000)$ & $* * *$ \\
\hline OLaNO & 0.013 & $(0.000)$ & $* * *$ & 0.003 & $(0.000)$ & $* * *$ \\
\hline Constant & 1.619 & $(0.002)$ & $* * *$ & 1.645 & $(0.002)$ & $* * *$ \\
\hline Pseudo Rsq & 0.136 & & & 0.192 & & \\
\hline No. of observations & 2926 & & & 2926 & & \\
\hline
\end{tabular}

Source: Authors, based on own calculations.

All models are weighted by the population. $\left(^{*}=p \leq 0.05 ;^{* *}=p \leq 0.01{ }^{* * *}=p \leq 0.005\right)$

The tranquil character of this election was evident especially in comparison with the 2014 presidential election, when Fico had permanently attacked Kiska at the personal level. (ČT 24, 2019). In the meantime, Čaputová's campaning focused on her future national agenda, especially on

${ }^{17}$ \#Siet' as a political party was dissolved after the 2016 parliamentary election. 
employing presidential soft power. Šefčovič had a television spot aimed at convincing the voters about his respectable status and political networks in international politics.

The first round of Čaputová vs Šefčovič presidential contest signified a clear outcome for both candidates. Only Fico in the 2014 election and Mečiar in the 2004 election did not defend victory from the first round and lost the election. In the first round, President Kiska lost to Fico just by 4 per cent, and it was by $10 \%$ in case of Gašparovič to Mečiar respectively. Diverse yet supportive speeches delivered by defeated candidates were of significant importance for Čaputová's victory in the second round. Initially, Béla Bugár, the leader of Most-Híd, openly backed Čaputová. Divergently, Šefčovič attempted to attract conservative voters and to mobilise the electorate of Smer-SD. Despite the fact that Šefčovič managed to mobilise more voters between the first and second round and thereby obtaining over 350,000 new votes, Čaputová received 186,000 new votes in total. Yet she experienced a landslide victory as in the first round and reached $58.4 \%$ to Maroš Šefčovič's 41.59\%.

In order to address the third research question, the authors have opted for the latter, since enables them to geographically demonstrate significant losses, or gains in a comparative way to the first round, respectively. As evident from Graph 6, that shows the above-described aspects in case of Čaputová, she managed to preserve her electoral support or even slightly soar in the margin of 0-20.00 per cent. Noticeably, at the level of 20.00$40.00 \%$, she even mobilised the voters in the Žilina regions (Liptov, Turiec, Orava), and the eastern part of the region of Prešov. In comparison with the first round, a crucial voters' shift, associated with the margin of 80.00$93.00 \%$, took place in the southern part of Trnava, Nitra, Banská Bystrica, and the region of Košice, inhabited by the Hungarian minority. The greatest losses in minor units maximised at the level of -17.64 per cent against the first round. This situation was spotted in the region of Prešov where the opposing candidate mobilised the voters more signally. In defiance of that, Čaputová's gains evinced a comparatively puissant growth of support, ranging between $20.00-40.00$ per cent when compared to other candidates. 
Graph 6: Differences in valid votes (\%) for Zuzana Čaputová Between the $1^{\text {st }}$ and $2^{\text {nd }}$ Round in the 2019 Presidential Election ${ }^{18}$

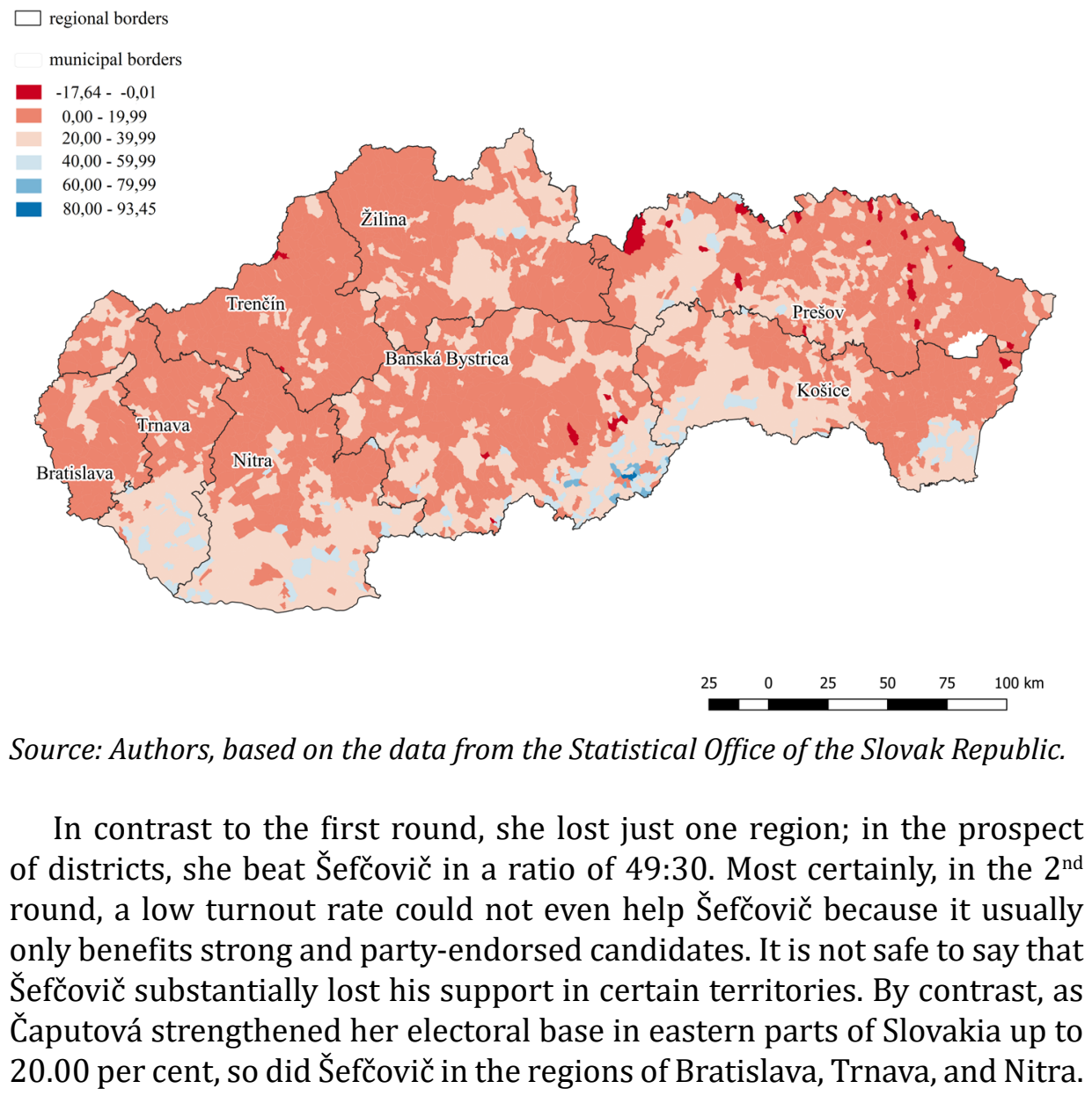

${ }^{18}$ Calculated as the second round minus the first one. 
Graph 7: Differences in valid votes (\%) for Maroš Šefčovič Between the $1^{\text {st }}$ and $2^{\text {nd }}$ Round in the 2019 Presidential Election. ${ }^{19}$

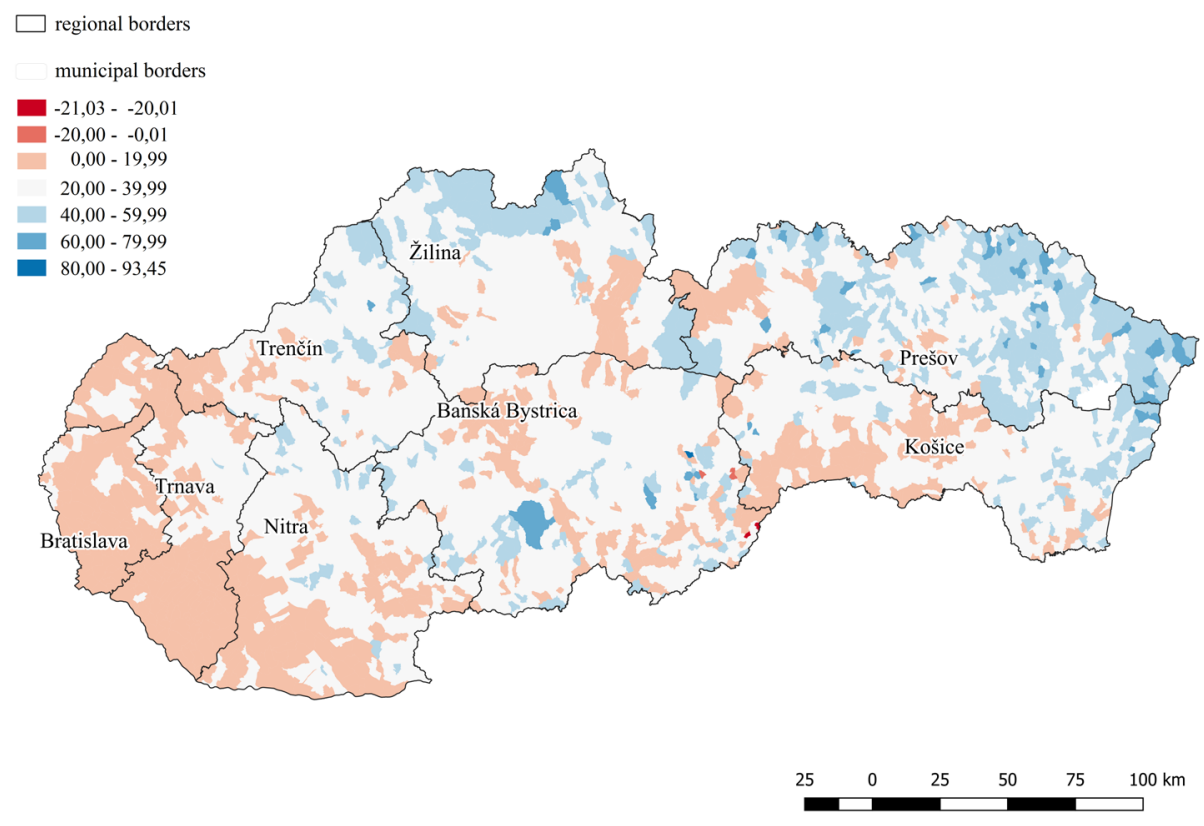

Source: Authors, based on the data from the Statistical Office of the Slovak Republic.

In total, Šefčovič gained the votes predominantly in the most Catholic parts of Slovakia, he lost in bigger towns or within the Hungarian community. Especially in a traditional bastion of the Smer-SD party, i.e. in the eastern part of Slovakia there was an increase of $40.00-60.00 \%$ and $60-80 \%$; then in the region of Orava and Kysuce in the north, and on the borderland between the regions of Trenčín and Žilina. Čaputová managed to remain ahead thanks to a wider scope of electorate comprising liberal voters in the towns of Bratislava, Košice, Banská Bystrica, and Žilina. Furthermore, she was successful more than expected in concrete areas of northern Slovakia, in the realms of Catholicism, as for instance in the Orava region or the town or Ružomberok, and eventually in the eastern part of the region of Prešov.

Regardless of Šefčovič's attempts to mobilise the voters, he did not achieve any success in obtaining enough voters in highly urbanised towns and cities. The key quartile of 0-20.00 per cent proved its significance in

${ }^{19}$ Calculated as the second round minus the first one. 
case of Čaputová. Not only she kept the electoral support from the first round, but she also augmented her electoral base across the whole country. Šefčovičs quartile of 0-20.00 per cent, on the other hand, did not attain this robust disposition.

\section{CONCLUSION}

This study aimed to the 2019 presidential election in Slovakia and its four strongest candidates in the main strongholds of their electoral support and respective socio-economic characteristics of their electorate at the level of municipalities whilst employing the aggregated data. The authors have revealed that Čaputová, the winning presidential candidate, gained the most significant support in highly urbanised areas, such as the region of Bratislava, Nitra, and Trnava in the first round. This candidate, however, received a low level of support on the outskirts of the Prešov and Košice regions. Šefčovič, the candidate defeated in the second round, was endorsed by regions traditionally supporting the Smer-SD party in the northeast of Slovakia, then in more religious, and less prosperous areas as Orava, Spiš, and Kysuce. Hungarian and southern areas were lukewarm towards the candidate in the first round. The levels of electoral support for Harabin and Kotleba overlapped in the region of Banská Bystrica and other northern territories as Kysuce and Orava. In contrast to Kotleba, Harabin's voters were akin to Šefčovič's in the eastern areas of Prešov and Košice.

Addressing the second research question has not been fruitful at first sight. In the course of research, it became obvious that presidential elections are so personalised that simply correlating electoral results by various socio-economic factors has proved unnecessary, since no satisfactory results could be identified. Eventually, personalised datasets might reveal further correlations. These, however, cannot be analysed at the level of towns.

Finally, when observing the voters' shifts between the first and second round, authors made the following observations. Both candidates mobilised their voters and supporters significantly, and none of them experienced any significant shrinkage in respect of supporting areas. However, Čaputová proved to be more successful due to a continual ability to sustain the electoral support, and on top of that, she even increased it up to 20 per cent in a vast majority of Slovakia's regions. And this also included the regions in which the Smer-SD party used to dominate (i.e., Prešov, Trenčín, northern parts of Žilina). And finally, a significant accumulation of votes for Čaputová arose in the south of Slovakia, and thus with the Hungarian 
minority. Šefčovič's rise in votes was only marginal in the western areas. Most importantly, though, he concentrated, albeit in an insufficient way, on traditional and conservative areas of Orava and Spiš. Consequently, he lost significant voters in the southern belt close to the Hungarian borders. Although Šefčovič turned at least one region to his advantage, it was not enough since the loss of ca 470,000 voters from the first round was reduced to just 304,000 voters in the second round.

On the one hand, the run-off system of voting, as used in the presidential elections, inclines towards a natural division of society into two blocks. On the other hand, this election has also demonstrated the existence of regional patterns of electoral support in both rounds of voting. Whereas Čaputová strongly relied on voters from the western part of Slovakia and other greater urbanised regional towns, Šefčovič's voters are found in the northeastern or central and less urbanised parts of Slovakia.

Albeit previously labelled as a liberal candidate due to her moderate points of view in terms of values and ethical issues (such as religion, abortions, euthanasia, etc.), Čaputová stayed able to obtain sufficient electoral support throughout. The lack of support towards Šefčovič in the south of Slovakia follows the nationalist and populist map of Vladimir Mečiar's electoral support in the second round of presidential election in which he stood against Rudolf Schuster, or alternatively, in 2004, when Mečiar ran for office in the second round of the same type of elections.

Čaputová's election victory indicates and affirms, among others, that the candidates with apolitical personal history or non-party, and thus independent, endorsed a long-standing trajectory of personalised politics, which has been widespread and popular in the Western democracies (Karvonen, 2010; Rahat, Shaefer, 2007; Garzia, 2011).

Needless to say, Čaputová may inspire other women, and thus become an incentive for them to take part in politics, albeit not at the highest level necessarily. On the other hand, citizens' disagreement with the results, as expressed by the low turnout in the second round, may turn out to be a trigger for a unification of populist and extremist forces in the Slovak political environment. Also, an essential determinant of Čaputová's future mandate will lie in her use of soft power more than ever during the Covid-19 era.

\section{REFERENCES}

APPLEBAUM, A. (2019). Slovakia's president suggests way out world's populist quagmire. In: The Washington Post, 15 October 2020 [online]. 
Available at: https://www.washingtonpost.com/opinions/2019/10/15/ slovakias-president-suggests-way-out-worlds-populist-quagmire/. [Accessed July 23, 2020].

APPlEBAUM, A. (2020). Twilight of democracy: The seductive lure of authoritarianism. New York: Doubleday, 2020, 208 pp.

ALLISON, P., WATERMAN, R. P. (2002). Fixed-effects negative binomial regression models. In: Sociological Methodology, Vol. 32, 2002, pp. 247265.

ÁGH, A. (2016a). The decline of democracy in East-Central Europe: Hungary as the worst-case scenario. In: Problems of Post-Communism, Vol. 63, No. 5-6, 2016, pp. 277-287.

ÁGH, A. (2016b). The deconsolidation of democracy in East-Central Europe: The new world order and the EU's geopolitical crisis. In: Politics in Central Europe, Vol. 12, No. 3, 2016, pp. 7-36.

BAHNA, M., KRIVÝ, V. (2016). Ako volili národnosti a konfesie v parlamentných vol'bách roku 1929 na Slovensku: možnosti nových metód ekologickej inferencie. In: Historický časopis, Vol. 64, No. 1, 2016, pp. 57-87.

BARÁTH, J., SZÖLLOS, J., ČERNÁK. P. (1995). Analýza stability územia volebnej podpory vybraných politických strán (na základe výsledkov volieb 1990, 1992 a 1994). In: Geografický časopis, Vol. 47, 1995, pp. 247-259.

BUČEK, J., PLEŠIVČÁK, M. (2017). Self-government, development and political extremism at the regional level: A case study from the Banská Bystrica Region in Slovakia. In: Sociológia, Vol. 49, No. 6, 2017, pp. 599635.

CIANETTI, L., DAWSON. J., HANLEY, S. (2018). Rethinking "democratic backsliding" in Central and Eastern Europe: Looking beyond Hungary and Poland. In: East European Politics, Vol. 34, No. 3, 2018, pp. 243-256.

CÍBIK, L. (2016). Implicit persuasion of voters in the 2012 Slovak Republic parliamentary election. In: Slovak Journal of Political Sciences, Vol. 16, No. 3, 2016, pp. 221-243.

ČT24. (2019). Prezidentská kampaň na Slovensku je klidnější než před pěti lety. In: ̌̌T 24.cz. [online]. Available at: https://ct24.ceskatelevize. cz/svet/2768156-prezidentska-kampan-na-slovensku-je-klidnejsi-nezpred-peti-lety. [Accessed July 10, 2019].

DATE, S. (2019). Negative binomial regression: A step by step guide. Towards Data Science. [online]. Available at: https://towardsdatascience.com/ negative-binomial-regression-f99031bb25b4. [Accessed June 20, 2020]. 
FILIPEC, O. (2019). Challenging trends within Slovak party system in the context of 2016 elections to the National Council of the Slovak Republic. In: Politics in Central Europe, Vol. 15, No. 1, 2019, pp. 7-34.

FITZMAURICE, J. (1998). Politics and government in the Visegrad countries. New York: St Martin's Press, 1998, 202 pp.

FITZMAURICE, J. (2001). The Slovak presidential election, May 1999. In: Electoral Studies, Vol. 20, No. 2, 2001, pp. 321-325.

FLEMING, M. (2006). The 2005 parliamentary and presidential elections in Poland: The geography of abstention. In: Debatte: Journal of Contemporary Central and Eastern Europe, Vol. 14, No. 2, 2006, pp. 91-118.

FOCUS. (2019). Preferencie kandidátov na podt prezidenta - február III. 2019. In: Focus-research.sk [online]. Available at: https://www.focusresearch.sk/files/269_Preferencie\%20prezidentsk\%C3\%BDch\%20 kandid\%C3\%A1tov_febru\%C3\%A1r\%20III_2019.pdf. [Accessed July 19, 2019].

FREEDMAN, D. A. (2009). Statistical models: Theory and practice. Cambridge: Cambridge University Press, 2009, 442 pp.

GARZIA, D. 2011. The personalization of politics in Western democracies: Causes and consequences on leader-follower relationships. In: The Leadership Quarterly, Vol. 22, No. 4, 2011, pp. 697-709.

GIBA, M. (2011). Vplyv priamej vol'by na ústavné postavenie prezidenta republiky na Slovensku. In: Acta Universitatis Carolinae Iuridica, No. 4, 2011, pp. 101-115.

GREGOR, K. (2015). Who are Kotleba's voters? Voters' transitions in the Banská Bystrica Region in 2009-2014. In: Sociológia, Vol. 47, No. 3, 2015, pp. 235-252.

HANLEY, S., VACHUDOVA, A. M. (2018). Understanding the illiberal turn: Democratic backsliding in the Czech Republic. In: East European Politics, Vol. 34, No. 3, 2018, pp. 276-296.

HAUGHTON, T., KRAUSE-DEEGAN, K. (2015). Hurricane season: Systems of instability in central and East European party politics. In: East European Politics and Societies and Cultures, Vol. 29, No. 1, 2015, pp. 61-80.

HENDERSON, K. (1999). Problems of democratic consolidation in the Slovak Republic. In: Society and Economy in Central and Eastern Europe, Vol. 21, No 3, 1999, pp. 141-178.

HILBE, J. (2011). Negative binomial regression. Cambridge: Cambridge University Press, 2011, 553 pp.

HLAVÁČ, M. (2016). Performance of political parties in the 2016 parliamentary election in Slovakia: regional comparisons and district- 
level determinants. In: Regional \& Federal Studies, Vol. 26, No. 3, 2016, pp. 433-443.

HORVÁTH, P., JUHÁS, P. (2011). Zavádzanie priamej vol'by prezidenta na Slovensku a jej dôsledky. In: Acta Universitatis Carolinae Iuridica, No. 4, 2011, pp. 115-128.

CHYTILEK, R., ŠEDO, J. (2009). Volební systémy. Praha: Portál, 2009, 376 pp. JOHNSTON, R. J. (2000). Electoral geography. In: Johnston, R. J. (eds.). Dictionary of human geography. Oxford: Blackwell Publishers, 2000, 581 pp.

JUST, P. (2019). Slovakia cabinet after 2016: From single party majority to motley crew. In: Journal of Comparative Politics, Vol. 12, No. 1, 2019, pp. 71-85.

KARVONEN, L. (2010). The personalization of politics: Astudy of parliamentary democracies. Colchester, ECPR Press, 2010, 124 pp.

KEREKEŠ, D. (2018). Vol'by 2016 v Košiciach: priestorová analýza. In: Sociológia, Vol. 50, No.1, 2018, pp. 31-56.

KNOTT, E. (2018). Perpetually "partly free": Lessons from post-soviet hybrid regimes on backsliding in Central and Eastern Europe. In: East European Politics, Vol. 34, No. 3, 2018, pp. 355-376.

KRIVÝ, V., FEGLOVÁ, V., BALKO, D. (1996). Slovensko a jeho regióny: sociokultúrne súvislosti volebného správania. Bratislava: Nadácia Médiá, 1996, 414 pp.

KRIVÝ, V. (2000). Politické orientácie na Slovensku: skupinové profily. Bratislava: IVO, 2000, $101 \mathrm{pp}$.

KRIVÝ, V. (2014). Od Malaciek po Čadcu: výsledky volieb 1920-2012. In: GONĚC, V., HOLEC, R. (eds.). Československá historická ročenka 2013. Skalica, Bratislava: SEVS, Veda, 2014, 311 pp.

LAUKOVÁ, L. (2018). Kiska nešiel podla ústavy, myslí si ústavná právnička. Čo bude nasledovat'? In: Hospodárske noviny, 20 March 2018. [online]. Available at: https://slovensko.hnonline.sk/1714501-kiska-nesielpodla-ustavy-mysli-si-ustavna-pravnicka-co-bude-nasledovat. [Accessed July 23, 2019].

LAND, K. C., McCALL, P. L., NAGIN, D. S., (1996). A comparison of Poisson, negative binomial, and semiparametric mixed Poisson regression models: With empirical applications to criminal careers. In: Sociological Methods and Research, Vol. 24, No. 4, 1996, pp. 387-442.

LEIB, J., QUINTON, N. (2011). On the shores of the 'Moribund Backwater': trends in electoral geography research since 1990. In: WARF, B., LEIB, J. (eds.). Revitalizing Electoral Geography. Burlington: Ashgate, 2011, 238 pp. 
MADLEŇÁK, T. (2012a). Regionálna diferenciácia volebného správania na Slovensku 1998-2010. Bratislava: Veda, 2012, 232 pp.

MADLEŇÁK, T., PINK, M. (2012b). Základné priestorové vymedzenie voličskej základne politických strán na Slovensku 1994-2010. In: PINK, M. (ed.). Volební mapy České a Slovenské republiky po roce 1993: vzorce, trendy, proměny. Brno: CDK, 2012, 264 pp.

MADLENÁK, T. (2017). Potential and real political representation of the regions of Slovakia. In: Geographia Cassoviensis, Vol. 11, No. 2, 2017, pp. 153-166.

MADLEŇÁK, T. BALÁŽOVIČ, L'. (2018). Politické preferencie miest na Slovensku v parlamentních volbách 1929. In: Geografie, No. 123, 2018, pp. 107-140.

MADLEŇÁK, T. (2019). The geographical representativeness of the deputies elected to the national council of the Slovak Republic in terms of single electoral district. In: Sociológia, Vol. 51, No. 5, 2019, pp. 483-501.

MAREŠ, P., RABUŠIC, L., SOUKUP, P. (2015). Analýza sociálněvědných dat (nejen) v SPSS. Brno: Munipress, 2015, 508 pp.

MAŠKARINEC, P. (2013). Prostorová analýza prezidentských voleb v České republice v roce 2013. In: Sociológia, Vol. 45, No. 5, 2013, pp. 435-469.

MIKUŠ, R., GURŇÁK, D., MÁRRIÁSSYOVÁ, A. (2013). Analýza volebnej podpory Mariána Kotlebu ako reprezentanta krajnej pravice v krajských vol'bách 2013. In: Sociológia, Vol. 48, No. 1, 2013, pp. 48-70.

MIKUŠOVIČ, D. (2019). Mistrík odstúpil z volieb a podporil Čaputovú, Kiska hovorí, že bude dobrou prezidentkou. In: Denník N. 26 February 2019. [online]. Available at: https://dennikn.sk/1393622/obrat-vo-volbachmistrik-odstupuje-a-podporuje-caputovu/. [Accessed July 23, 2019].

MORTKOWICZ, S. (2019). Political outsider wins Slovakia's presidential election. In: Politico, 31 March 2019. [online]. Available at: https:// www.politico.eu/article/political-outsider-wins-slovakias- presidentialelection-zuzana-caputova-maros-sefcovic/. [Accessed November 15, 2019].

NORRIS, P. (1997). Choosing electoral systems: proportional, majoritarian and mixed systems. In: International Political Science Review, Vol.18, No. 3, 1997, pp. 297-312.

OSGOOD, D. W. (2000). Poisson-based regression analysis of aggregate crime rates. In: Journal of Quantitative Criminology, Vol. 16, No. 1, 2000, pp. 21-43.

PATTIE, C., JOHNSTON, R. (2009). Electoral geography. In: KITCHIN, R., THRIFT, N. (eds.) International encyclopedia of human geography. 
Amsterdam: Elsevier Science, 2009, 8250 pp.

PINK, M. (2012). Volební mapy České a Slovenské republiky po roce 1993: vzorce, trendy,proměny. Brno: CDK, 2012, 264 pp.

PINK, M., SPÁČ, P. (2012). Prezidentské vol'by na Slovensku. In: Volební mapy České a Slovenské republiky po roce 1993: vzorce, trendy,proměny. Brno: CDK, 2012, 264 pp.

PLEŠIVČÁK, M. (2011a). Postavenie regiónov Slovenska z hladiska území volebnej podpory politických strán $\mathrm{v}$ parlamentných vol'bách v rokoch 2002-2010. In: Geografický časopis, Vol. 63, No. 3, 2011, pp. 227-251.

PLEŠIVČÁK, M. (2011b). Regionálny obraz korelačnej závislosti medzi volebnými preferenciami a vybranými sociálnymi charakteristikami populácie Slovenska. In: Regionální studia, Vol. 5, No. 1, 2011, pp. 2-16.

PLEŠIVČÁK, M. (2013). The regional dimension of the socio-political urbanrural conflict in Slovakia. In. Acta Universitatis Carolinae Geographica, Vol. 48, No. 1, 2013, pp. 47-58.

PLEŠIVČÁK, M. (2014). Socio-ekonomická kompozícia spoločnosti a jej vplyv na teritoriálne vzorce volebného správania: prípadová štúdia regiónov západného Slovenska. In: Sociológia, Vol. 46, No. 1, 2014, pp. 25-59.

PRZYBYL, V. (2019). Vliv vybraných demografických charakteristik na volební chování na Slovensku v meziválečném období. In: Geografický časopis, Vol. 71, No. 2, 2019, pp. 181-199.

RAHAT, G., SHEAFER, T. (2007). The personalization(s) of politics: Israel, 1949-2003. In: Political Communication, Vol. 24, No. 1, 2007, pp. 65-80. ROHN, T. (2019). Es sah so aus, als wäre die Slowakei ein Mafia-Staat. In: Die Welt, 4 May 2019. [online]. Available at: https://www.welt.de/politik/ ausland/article192911739/Staatspraesident-Kiska-ueber-Korruptionin-der-Slowakei.html. [Accessed August 16, 2019].

RYBÁŘ, M. (2010). The 2009 presidential election in Slovakia. In: Electoral Studies, Vol. 29, No. 1, 2010, pp. 171-173.

RYBÁŘ, M. (2005). The presidential election in Slovakia, April 2004. In: Electoral Studies, Vol. 24, No. 2, 2005, pp. 333-338.

RYBÁŘ, M., SPÁČ, P. (2015). The March 2014 presidential elections in Slovakia: the victory of a political novice. In: Electoral Studies, Vol. 38, 2015, pp. 88-90.

RYBÁ̌̌, M., SPÁČ, P. (2017). The March 2016 parliamentary elections in Slovakia: A political earthquake. In: Electoral Studies, Vol. 45, 2017, pp. 153-156.

SPÁČ, P. (2013). Slovakia: In search of limits. In: HLOUŠEK, V. (eds). Presidents above parties? Presidents in Central and Eastern Europe, Their Formal 
Competencies and Informal Power. Brno: Masaryk University Press, 2013, pp. 121-143.

STOREY, D. (2009). Political geography. In: KITCHIN, R., THRIFT, N. (eds.) International encyclopedia of human geography. Amsterdam: Elsevier Science, 2009, $8250 \mathrm{pp}$.

SZŐLŐS, J. (2006). Regióny volebnej podpory vybraných politických strán v parlamentných vol'bách 1998, 2002 a 2006. In: Geografická revue, No. 2, 2006, pp. 650-669.

ŠVIDROŇOVÁ, M., KAŠČÁKOVÁ, A., BAMBUSEKOVÁ, G. (2019). Social media in the presidential election campaign: Slovakia 2019. In: Administratie si Management Public, Vol. 33, 2019, pp. 181-194.

THE SLOVAK CONSTITUTION. (2015). [online]. Available at: https://www. ustavnysud.sk/ustava-slovenskej-republiky. [Accessed September 23, 2019].

TASR. 2019. Prieskum: Vol'by by vyhral SMER-SD, Kiska by získal iba 6 percent. In: eTrend.sk, 12 June 2019. [online]. Available at: https://www. etrend.sk/ekonomika/prieskum-volby-by-vyhral-smer-druhi-by-boliprogresivci-a-treti-kotlebovci.html. [Accessed November 10, 2019].

TKÁČ, A. (2019). Mistrík odstupuje a podporí Čaputovú. In: Postoj.sk, 26 February 2019 [online]. Available at: https://www.postoj.sk/40985/ mistrik-odstupuje-a-podpori-caputovu. [Accessed July 20, 2019].

UCLA. (2020). Negative binomial regression. Institute for Digital Research \& Education [online]. Available at: https://stats.idre.ucla.edu/stata/dae/ negative-binomial-regression/. [Accessed June 20, 2020].

WALKER, S. (2019). Slovakia's first female president hails victory for progressive values. In: The Guardian, 31 March 2019 [online]. Available at: https://www.theguardian.com/world/2019/mar/31/slovakiaelects-zuzana-caputova-first-female-president. [Accessed November 15, 2019].

ZVADA, L. (2018). Securitization of the migration crisis and Islamophobic rhetoric: The 2016 Slovak parliamentary election. In: Journal of Nationalism, Memory \& Language politics, Vol. 12, No. 2, 2018, pp. 216235. 